\title{
Dialectical anthropology and class struggle: a closer look at the Wobblies and their socialist allies
}

\author{
Paul LeBlanc ${ }^{1}$ (D) \\ Published online: 1 February 2018 \\ (C) The Author(s) 2018. This article is an open access publication
}

\begin{abstract}
The boldly interdisciplinary essay by Durrenberger and Doukas usefully opens a discussion of class and class struggle in the USA relating to the crises of our time. The discussion may be advanced through a critical engagement with what they have written. Approaching the question of class historically can provide a greater sense of motion, of the past flowing into the future. The citation by Durrenberger and Doukas of the Industrial Workers of the World (IWW) calls out for a more detailed examination of IWW thinking regarding stratification within the working class. This can enrich what the two authors have to say on the matter. An examination of race and racism by IWW-affiliated radicals provides additional insights and challenges. Finally, the authors' one-sided view of the Progressive Era (1900-1920) seems to miss the quality of "contested terrain" which suggests approaches that might benefit activists of today.
\end{abstract}

Paul Durrenberger and Dimitra Doukas offer an admirable kick-off to a discussion of class and class struggle in the USA, quite appropriate for a journal associated with the Marxist tradition. Pushing past academic boundaries, they provide historical survey, sociological reflections, and practical prognoses worthy of political scientists. Such a boldly interdisciplinary approach is entirely appropriate and necessary for those who would come to grips with the crises of our time.

Some of the most outstanding scholars have most fruitfully pushed past academic and scholarly boundaries in a similar manner. One thinks of W. E. B. Du Bois, who showed little hesitation in combining sociology with history and economics and politics in wrestling with the issues of racial injustice, imperialism, and the power of the "haves" over the "have-nots" (Lewis 1995, Mullen 2016). Eleanor Leacock's radical anthropology_explicit in its Marxism and feminism - did the same sort of thing in the exploration of pre-capitalist cultures (Leacock 1981, Leacock 1982). Herbert Gutman's fusion of labor history with the conceptualizations of cultural anthropology resulted in similar breakthroughs (Gutman 1977, Gutman 1992). These and others like them sought to utilize multiple disciplines to better understand the world - and to help those who would struggle to change it.

Paul LeBlanc

Paul.LeBlanc@LaRoche.edu

1 Pittsburgh La Roche College, 9000, Babcock Blvd, Pittsburgh, PA 15237, USA 
In the spirit of such mentors as these, I will contradict some of what Durrenberger and Doukas have to say, in hopes of contributing to a higher synthesis. Such dialog can, perhaps, help move forward the conversation they have so admirably initiated. This commentary also seeks to add (but can by no means complete) elements to the story of past strugglesadditional pieces will need to be added by others. Collectively sorting through aspects of the past may provide insights into "what is to be done" in the time stretching before us.

\section{Class and class struggle}

Durrenberger and Doukas begin their discussion of class with a static definition as "a group of people who enjoy the same access to resources as other members of the same class in a state that supports a system of stratification via ideological and physical means." Another way of framing the issue would reach for a greater sense of motion, of the past flowing into the future.

The modern usage of the term class refers to differences of wealth and power in society. This is interconnected with the rise of civilization - dependent upon the technological development and consequent increase in productivity that results in the production of a socioeconomic surplus, which, in turn, makes it possible for the labor of one person to support himself/ herself as well as one or more others.

This, in turn, makes possible the rise of the socioeconomic inequality that is essential to the modern concept of class. The rise and development of civilization have involved two primary type classes: (a) the exploited majorities whose labor sustains all of society and (b) the powerful minorities whose wealth depends on the exploitation of the majority's labor. The traditional Marxist schema of successive stages of class society, based on European history, has seen ancient slave-based civilizations (with slaves and slave-owners) superseded by feudal society (with peasant serfs and powerful lords), which in turn has been replaced by capitalism (with the proletariat, or working class, and the bourgeoisie, or capitalist class). It is the struggle between the working class and the capitalist class, according to Marx and Engels, that will define the trajectory of modern society - culminating in a victory of the working-class majority, leading in turn to a revolutionary transition from capitalism to socialism (Le Blanc 2016).

\section{Wobbly era artifacts}

Durrenberger and Doukas capture some of what is suggested above by quoting from the Marxist-influenced 1905 preamble to the constitution of the Industrial Workers of the World (the IWW, often known affectionately as "the Wobblies"). Unfortunately, the authors then tell us something that is, at best misleading:

The IWW preamble did not foresee that the employing class would successfully elevate a significant number of the working class beyond the level of hunger and want, create and perpetuate a culture of self-justification for them, and give them access to a substantial quantum of the good things of life, along with a parallel ideology of consumption to fuel both the need for these products and the desire to serve the capitalist class to gain the means for acquiring them. In doing so, they created a widespread experience of middle class comfort which became the pragmatic basis for the myth of 
the middle class. ... The capitalist class was able to buy off the middle class with access to consumer goods. (Durrenberger and Doukas)

A problem with this modern-sounding critique is that many of the Wobblies and their supporters were saying much the same thing in the heyday of the IWW. Among the left-wing socialist intellectuals who were close to (and whose writings were read by) the Wobblies were Jack London, Austin Lewis, and William English Walling, and in their writings, one can find accounts of the wheel of misfortune that more modern writers have knowingly "discovered" (Buhle 1970, 42; Foner 1965, 151, 267-9, 409-10).

In his 1907 futuristic novel The Iron Heel, Jack London wrote of the leader of a skilled craft union insisting that "charity begins at home," and that "it's my business to consider the interests of the men I represent, that's all." A situation would develop in which "the labor castes, the members of the favored unions," would look after themselves, turning their back on the great bulk of unskilled workers: "Wages are going to be advanced and hours shortened in the railroad unions, the iron and steel workers unions, and the engineer and machinist unions," with other labor organizations "ground out of existence" (London 1907, 221, 222, 225).

Austin Lewis's succinct left-wing study, The Militant Proletariat, describes the "skilled laborer possessing the commodity of skilled labor" seeking only to improve the conditions of those in possession of such skills. With the "instinct of self-preservation which leads one to consider only himself in times of strife, his attention is riveted upon his own craft," thereby pressing for the "improvement in the position of members of a given craft without any improvement in the position of labor as a whole" (Lewis 1911, 101-102). An examination of "Class Struggle within the Working Class" in William English Walling's Progressivism-And After comments that "the social class ... variously referred to as the skilled workers, the upper layers of labor, or the aristocracy of labor, is based on a privileged occupation, a higher income, and opportunities above those of the average wage-earner or his children" (Walling 1914, 207).

This dynamic afflicted the American Federation of Labor (AFL), which - despite its partly socialist origins (and an ongoing socialist opposition within it) - was based largely on craft unions of skilled workers and was dominated by the de-radicalized and increasingly bureaucraticconservative leadership associated with ex-socialist Samuel Gompers. And it accounts in part for the fierce and often debilitating hostilities that flared up between the AFL and IWW.

Yet it is hardly inevitable that skilled workers must become self-centered and privileged labor aristocrats. While Samuel Gompers emphasized the pragmatic ethic of a "pure and simple" trade unionism sticking simply to the improvement of union members' wages, hours, and working conditions, on the other side of the world, V.I. Lenin in the same period insisted revolutionary working-class organizers must function not simply as a trade union secretaries but must "tribunes of the people." In Russia, a growing number of skilled workers rejected the "labor aristocrat" option and rallied to the perspective of building genuine class-consciousness by fighting against all forms of oppression afflicting the working class and all of society. (On Gompers, see Kaufman (1973) and Mandel (1963); on the Leninist alternative, see Le Blanc (2015) and Le Blanc (2016) 237-280.)

This was the option for which IWW organizers were also reaching. Elizabeth Gurley Flynn, for example, explained the necessary link between practical struggles and revolutionary spirit:

What is a labor victory? I maintain that it is a twofold thing. Workers must gain economic advantage, but they must also gain revolutionary spirit, in order to achieve a 
complete victory. For workers to gain a few cents more a day, a few minutes less a day, and go back to work with the same psychology, the same attitude toward society is to achieve a temporary gain and not a lasting victory. For workers to go back with a classconscious spirit, with an organized and determined attitude toward society means that even if they have made no economic gain, they have the possibility of gaining in the future. In other words, a labor victory must be economic, and it must be revolutionizing (Kornbluh 1988, 215).

\section{The color line}

In pushing against the notion of such identities as race and gender "trumping" class, Durrenberger and Doukas help advance the discussion of "what is to be done," and one might draw as well from comments in Roger Lancaster's brilliant anthropological study Life is Hard:

The class dimension is privileged, if only circumstantially and politically (not analytically), and by this index: class exploitation necessarily produces an exploiting minority and an exploited majority. The same cannot be said for any other dimensions of oppression. Whether one is seeking to reform or overthrow any system of exploitation, the dynamics of class and class resistance remain, in Marx's sense, strategic and paramount (Lancaster 1992, 282).

But at the same time, the authors' point seems limited by remaining at too high a level of abstraction. A more intimate wrestling with the realities of racism and attention to the intersections of class with other identities are necessary as we seek to understand the past, engage with the present, and shape the future.

The classic comment of Du Bois that "the problem of the twentieth century is the problem of the color-line" was echoed — within proletarian context — by the comment of Ben Fletcher, the most prominent African American IWW organizer: "In these United States, the history of organized labor movement's attitude and disposition toward the Negro section of the world of industry is replete with gross indifference and, excepting a few of its component parts, is a record of complete surrender before the color line" (Cole 2007, 103). And as Robert L. Allen later emphasized, far from this being simply attributable "to the misleadership of labor bureaucrats and conniving capitalist bosses, ... many rank-and-file union members have been and are just as racist as the ore bigoted labor leaders and employers" (Allen and Allen 1974, 167). Black poet and journalist Claude McKay, associated with the pro-IWW and revolutionary socialist left, emphasized in the early 1920s that "the prejudices have sunk their roots so deeply that it will probably require time for the energetic educational work which will lead to the desired results" of inter-racial solidarity within the US working class (McKay 1979, 5).

In the twentieth century's first two decades, however, anti-racist educational work within the Socialist Party and the IWW could hardly be termed "energetic." Noting that within the Socialist Party of America, there co-existed unashamedly racist and uncompromisingly antiracist attitudes, Sally Miller comments that it "moved through its first two decades acknowledging the Negro in a rather absent-minded fashion," and in one of the most "advanced" statements of the Party's position maintained that "the oppression of the Negro was due to class rather than to race and the remedy was prescribed to be working class solidarity" (Miller 
1996, 37, 41). Even within the IWW, which by all accounts was the most consistently antiracist organization on the left, the careful scholarship of Franklin Rosemont reveals that "the IWW's attitudes on race, and on the relation of race and class, were contradictory, full of loose ends, troubling ambiguities, and unresolved problems" (Rosemont 2003, 234). Militant black leftist W. A. Domingo was scathing in his critique of "many whites" who "assure themselves and their friends that they are irreconcilable enemies of the existing order" but whose radicalism "does not extend to colored peoples," treating blacks "patronizingly or opportunistically." Domingo concluded: "One can boldly say that in America the Negro question is the touchstone, the measure by which the sincerity of American radicalism can be measured" (McKay 1979, 39, 40).

Indeed, in rejecting the common left-wing dismissal of "race consciousness," Claude McKay — while by no means rejecting the need for blacks to develop "a class point of view and to join the class struggle"-insisted that "for the Negro in America it is very useful to be imbued with race consciousness." He commented that "the American Negro who was not imbued with race consciousness would constitute a strange phenomenon," since "the Negro in America is not permitted for one minute to forget his color, his skin, or his race" (McKay 1979, 4). The kind of interweaving consciousness that McKay pointed toward was not realized until the 1930s, largely through efforts within the Communist Party (Kelley 1994, Solomon 1998). It was not until the 1940s that C.L.R. James was able to theorize this kind of synthesis, with the added insights of "intersectionality" provided by radical black feminists in the 1960s and 1970s (James 1996, James 2018, Taylor 2017).

Related to the ideological limitations that cut across the possibility of such advances during the heyday of the IWW and the Socialist Party of America, there were also structural limitations. The Wobblies were focused on struggles in the workplace; the Socialist Party was focused on the ballot box - each representing frameworks that were perhaps too narrow for the working-out of intersectional insights and struggles that may have required the broader contexts of community-based social movements (Barker et al. 2014).

\section{Contested terrain}

A jarring note in the historical analysis offered by Durrenberger and Doukas is the way in which they make Andrew Carnegie and other corporate capitalists primary symbols of the Progressive Era. In some ways, this finds reflection, as well, in a limited vision of the early twenty-first century. The terrain they stake out - both historically and in the present timeseems to me far more contested than their analysis appears to allow.

As they note, powerful forces were certainly at work, in the first two decades of the twentieth century, seeking to conserve and expand the power of corporate capitalism through interpenetrations with the state, with a variety of social reform efforts, and with multiple "progressive" efforts to craft a more durable social order. One might argue that Teddy Roosevelt and Woodrow Wilson are more appropriate representatives of this than the aging steel baron. But there are more fundamental issues at stake.

The Progressive Era was a period that saw the upwelling of innumerable efforts to improve the conditions of a majority of the people, independently of business interests: militant struggles around labor rights and the living conditions and working conditions of the working class; opposition to racism; uncompromising efforts to advance women's rights, including the right to vote and the right to reproductive freedom. Centrally involved in all of these struggles 
were socialists who were determined not to enhance the efficiency of a corporate capitalist order, but rather to replace it with economic democracy and a cooperative commonwealth.

The multi-faceted nature of issues and struggles in this contested terrain of the Progressive Era - it has already been suggested - provided complex challenges that the syndicalism of the Wobblies and the electoralism of the Socialists were ill-fitted to meet. The political program for the working class advanced in the Communist Manifesto of Marx and Engels, however, suggests a more sophisticated blend in which the "party" of revolutionary activists becomes integrated with three distinct but interrelated spheres of action - trade unions focused at the workplace, social movements engaged with community-wide issues, and an electoral-oriented labor party seeking to "win the battle of democracy" and take political power in order to initiate a revolutionary transition from capitalism to socialism. The multi-faceted struggle to win short-term victories against oppression would build the consciousness, experience, skills, and political power to end an oppressive system. "The struggle for reforms is its means, the social revolution its aim," as Rosa Luxemburg once put it (Le Blanc 2016, 201).

The IWW engaged in a contradictory effort to be the vehicle through which such a process could be facilitated. Functioning both as "a union of all the workers" and an organization of "selected revolutionists ... a revolutionary party," former Wobbly James P Cannon once put it, resulted in a duality that "hampered its effectiveness in both fields" (Cannon 1962, 340), nor could it provide an adequate framework for issue-driven social struggles beyond the workplace.

In the 1920s, Cannon and veterans from the IWW and left-Socialist milieu, sought to learn from their partial triumphs and undeniable failures. Many of them labored to build a more effective multi-faceted effort, through the US Communist Party, which would allow for the building up and dynamic interplay of revolutionary party, trade unions, social movements, and independent labor electoral efforts (Palmer 2007). Despite serious limitations, such efforts had powerful impact in working-class insurgencies of the 1930s, culminating in important gains, despite eventual defeats (Fried 1997, Ottanelli 1991, De Caux 1971, Preis 1972).

Explorations of these past experiences may provide useful lessons as we navigate the contested terrain of our own time. Working together, perhaps, we can craft insights that can help build a working-class alternative to the status quo. Some whose desperation has currently made them vulnerable to reactionary demagogues might even be attracted to a militant social movement dedicated to a cooperative commonwealth, in which the free development of each is the condition for the free development of all.

Open Access This article is distributed under the terms of the Creative Commons Attribution 4.0 International License (http://creativecommons.org/licenses/by/4.0/), which permits unrestricted use, distribution, and reproduction in any medium, provided you give appropriate credit to the original author(s) and the source, provide a link to the Creative Commons license, and indicate if changes were made.

\section{References}

Allen, Robert L., and Pamela P. Allen. 1974. Reluctant Reformers: The Impact of Racism on American Social Reform Movements. Washington, DC: Howard University Press.

Barker, Colin, Laurence Cox, John Krinsky, and Alf Gunvlald Nilsen, eds. 2014. Marxism and Social Movements. Chicago: Haymarket Books.

Buhle, Paul. 1970. Intellectuals in the Debsian Socialist Party. Radical America 4 (3): 35-61.

Cannon, James P. 1962. The First Ten Years of American Communism. New York: Lyle Stuart. 
Cole, Peter, ed. 2007. Ben Fletcher: The Life and Times of a Black Wobbly. Chicago: Charles H. Kerr.

De Caux, Len. 1971. Labor Radical: From the Wobblies to CIO, A Personal History. Boston: Beacon Press.

Foner, Philip S. 1965. History of the Labor Movement in the United States, Volume IV: The Industrial Workers of the World, 1905-1917. New York: International Publishers.

Fried, Albert, ed. 1997. Communism in America: A History in Documents. New York: Columbia University Press.

Gutman, Herbert G. 1977. Work, Culture and Society in Industrializing America. New York: Vintage Books.

Gutman, Herbert G. 1992. In Power and Culture: Essays on the American Working Class, ed. Ira Berlin. New York: The New Press.

James, C.L.R. 1996. In C.L.R. James on the "Negro Question,", ed. Scott McLemee. Jackson: University of Mississippi Press.

James, C.L.R. 2018. In C.L.R. James and Revolutionary Marxism: Selected Writings of C.L.R. James, ed. Scott McLemee and Paul Le Blanc. Chicago: Haymarket Books.

Kaufman, Stuart Bruce. 1973. Samuel Gompers and the Origins of the American Federation of Labor, 18481896. Greenwood: Praeger.

Kelley, Robin D.G. 1994. Race Rebels: Culture, Politics, and the Black Working Class. New York: The Free Press.

Kornbluh, Joyce L., ed. 1988. Rebel Voices: An IWW Anthology. Chicago: Charles H. Kerr.

Lancaster, Roger N. 1992. Life Is Hard: Machismo, Danger, and the Intimacy of Power in Nicaragua. Berkeley: University of California Press.

Leacock, Eleanor Burke. 1981. Myths of Male Dominance: Colleted Articles on Women Cross-Culturally. New York: Monthly Review Press.

Leacock, Eleanor Burke. 1982. Marxism and Anthropolgy. In The Left Acadamy: Marxist Scholarship on American Campuses, ed. Bertell Ollman and Edward Vernoff. New York: McGraw-Hill.

Le Blanc, Paul. 2015. Lenin and the Revolutionary Party. Chicago: Haymarket Books.

Le Blanc, Paul. 2016. From Marx to Gramsci: A Reader in Revolutionary Marxist Politics. Chicago: Haymarket Books.

Lewis, Austin. 1911. The Militant Proletariat. Chicago: Charles H. Kerr.

Lewis, David Levering, ed. 1995. W.E.B. Du Bois: A Reader. New York: Henry Holt and Co..

London, Jack. 1907. The Iron Heel. New York: Grosset and Dunlap.

Mandel, Bernard. 1963. Samuel Gompers, A Biography. Yellow Springs: Antioch Press.

McKay, Claude. 1979. The Negroes in America. Port Washington: Kennikat Press.

Miller, Sally M., ed. 1996. Race, Ethnicity, and Gender in Early Twentieth-Century American Socialism. New York and London: Garland Publishing.

Mullen, Bill V. 2016. W. E. B. Du Bois: Revolutionary Across the Color Line. London: Pluto Press.

Ottanelli, Fraser M. 1991. The Communist Party of the United States: From the Depression to World War II. New Brunswick, NJ: Rutgers University Press.

Palmer, Bryan D. 2007. James P. Cannon and the Origins of the American Revolutionary Left, 1890-1928. Urbana and Chicago: Illinois University Press.

Preis, Art. 1972. Labor's Giant Step: The First Twenty Years of the CIO, 19336-55. New York: Pathfinder Press.

Rosemont, Franklin. 2003. Joe Hill: The IWW and the Making of a Revolutionary Workingclass Counterculture. Chicago: Charles H. Kerr.

Solomon, Mark. 1998. The Cry Was Unity: Communists and African Americans, 1917-1936. Jackson: University of Mississippi Press.

Taylor, Keeanga-Yamata, ed. 2017. How We Get Free: Black Feminism and the Combahee River Collective. Chicago: Haymarket Books.

Walling, William English. 1914. Progressivism—and After. New York: Macmillan Co.. 